\title{
Living in Huntara during the Covid-19 Pandemic (Communication Ethnography of the PASIGALA Earthquake Victims Amid the Covid-19 Pandemic)
}

\author{
Sudarwin S \\ Social Science Study Program Postgraduate Doctoral Program, Tadulako University, Indonesia
}

\begin{abstract}
This research is motivated by the term waste and ba kojo as a communication event of the community living together at the Taipa Beach shelter due to the earthquake on September 28th, 2018, in Palu city. The purpose of this study is to describe and know in-depth the communication patterns between fellow disaster survivors and between disaster survivors and related parties, in this case, the Palu city government, both verbal and nonverbal. To achieve this goal, the researcher uses an ethnographic approach to communication through qualitative methods. Determination of informants as many as 14 (fourteen) people using purposive sampling. The instrument in this study used participant observation and non-participant observation, in-depth interviews, and documentation. Technique analysis data using interactive model analysis data by Miles and Huberman with triangulating methods, the sources of data, and theories. The leading idea used as a reference in this study is the ethnography of communication by Hymes with combined of Berger's approach in terms of social life and related to the dialectic of externalization, objectivation, and internalization. The results of this study reveal: (1) the communication patterns of fellow Taipa beach disaster survivors are influenced by the state of the environment where they live through transcendental communication. (2) The communication pattern of disaster survivors with related parties (government) has experienced many obstacles due to the relationship with bureaucratic communication patterns.
\end{abstract}

Keywords: Living in shelters during the covid 19 pandemic, the Ethnography of Communication, Earthquake Victims

\section{INTRODUCTION}

$\mathrm{T}$ here is a new community which we call the Huntara community. There were people from a variety of different backgrounds. Their presence was due to an earthquake natural disaster accompanied by liquefaction and shock on September 28th, 2018. This event became known as the Pasigala earthquake, an abbreviation of the three affected areas, namely Palu City, Sigi Regency, Parigi Regency, and Donggala Regency. This incident has changed the social life of the people directly affected by the natural disaster (Wekke et al., 2019; Partelow, 2021). However, this research will deepen the study in terms of communication, how the communication phenomenon is, how they build communication, the content of the touch, and the mechanism of communicating with new people, meeting in new places and new ethnic groups.
In his initial research, he saw the ethnography of communication as an approach to how people understand themselves and their lives through communicating. After doing research, I found that at the beginning, the communication was acceptable. Still, there was a change in the communication process from harmonious to already a conflict in it in the middle. Still, after doing research, there was something more interesting than that, what is the problem of conveying terms, ideas, new ideas in communication events that people have never researched that communication is what we know communication theory is the delivery of messages or pictures or the exchange of messages to other people, that's what many people know. It turns out that communicating is not just conveying messages so that communication occurs. Still, in the event of contact, it may give birth to new terms, ideas, or ideas for the community how it happened through an intense process with the district. The intensity process will occur in the presence of an event.

According to (Hymes, 1972), in the ethnography of communication, there are several speech acts such as participant, context, message, method, and others; this theory is used as an essential reference to provide the context structure of the created communication. Ethnography observes that language, its meaning and usage, speech structure or genre, and choices of language functions are governed by socio-cultural norms that run and apply in the ethnic group of language users, as stated (Hymes, 1972; Sybing, 2021) that a sentence or a series of words in the same syntactic relationship, may mean a request, command, praise, insult, depending on the understanding that exists in society.

The language that uses a system of norms and rules is part of cultural integration. The language used in communication situations, events, and actions is beneficial in recognizing cultural norms that underlie a person's behavior because culture is created, negotiated, and defined continuously in step among people. -people who participate in various interactive situations (Kersten-Pejanić, 2019; Nicodemus et al., 2021). (Hymes, 1962; van der Wilt et al., 2021)argues that language competence is the knowledge that focuses on communicative competence, namely the use of language determined by social, psychological, cultural background, and understanding of the language. In a community, the relationship between people or ethnicity communicates is a communicative aspect that must 
be considered. This speech model can be studied with an ethnographic approach to communication.

This study will discuss how a communication event not only knows how messages are exchanged, but it turns out that communication events are also events that allow the birth of new terms, ideas, or ideas in the communication process in the community. According to (Berger \& Luckmann, 1991; Penuudi et al., 2020), In terms of community life, society is an objective reality and a subjective reality. As a factual reality, society seems to be outside of man and face-to-face with him.

This research's focus examines communicative situations, communicative events, and communicative actions both verbally and nonverbally. How the communication system was formed gave birth to new words, ideas, or ideas from people still surviving in the Huntara during the COVID19 pandemic. That is by identifying situations, events, and communicative actions in the communication process that repeatedly occur (recurrent events) and how one term, one idea, or idea can be present through communicating in an event.

\section{METHODOLOGY}

The type of research used in this research is qualitative using descriptive method. According to (Morris et al., 2021), the term qualitative research is intended as a type of research whose findings are not obtained through statistical or other computational procedures.

\section{Sampling and Data Collection}

This research was conducted in Taipa Hunting, North Palu District, Palu City, Central Sulawesi Province. The research subjects are survivors of the pasigala natural disaster in Taipa Shelter and were selected using the purposive sampling technique. The topics were chosen intentionally according to the needs of the required subjects.

The main criteria in determining informants are the phenomenon under study, interest in understanding and deepening its meaning, willingness to participate in in-depth interviews, and allowing researchers to record interviews and involve them for scientific purposes. In this study, the data collected are in the form of words and not numbers; the results obtained in the field are actual results and not engineered; the data or information obtained during the research is a natural setting or not made up (Mulyana, 2008; Wong \& Chan, 2021).

Based on the data analysis technique proposed by (Miles et al., 2014) includes four concurrent activities, namely: 1) data collection, 2) data reduction, 3) data presentation, and 4) conclusion drawing (verification).

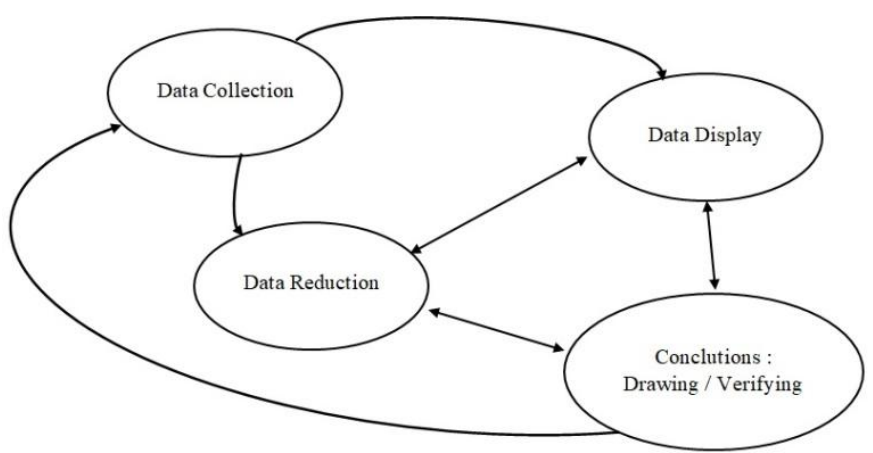

Figure 1. Data Analysis Components: Interactive Model

\section{RESULTS AND DISCUSSION}

Result

Description of the State of the Research Site at Taipa Beach Huntara

Geographically, Taipa Beach Huntara is located in Taipa Village with a coastal view to the west, one of the private sector's tourist attractions. To the south, east, and north it is surrounded by thickets and plantations of the Taipa natives. To reach this shelter, it takes 17 minutes by a 4wheeled vehicle, which is approximately $2 \mathrm{~km}$ from the resident's village and $5 \mathrm{~km}$ from the city center of Palu. The number of shelters built by PUPR Palu City is 132 shelter rooms with $6 \times 6$ meters. Of that number occupied by 58 families with 290 people. In addition, the public facilities provided are only a simple prayer room and simple street lighting. The shape of the building is facing each other to be occupied by eight families.

\section{Description of Community Economic Conditions in Taipa Beach Huntara}

In general, the condition of the community before the Pasigala earthquake was those who lived near the Talise coast. They have an entrepreneurial profession by selling various types of food and drinks on the Talise beach. The results of several interviews above show that basically before the terrible disaster, the lives of earthquake survivors who lived in Taipa Shelter had decent jobs and livelihoods. However, they generally occupied building land that was either renting out or renting out, so this is an obstacle they have to face with the requirements. Hunt recipients must have a homeownership certificate.

Description of the communication process at Taipa Beach Huntara

The disaster in September 2018 in Palu left deep wounds for the victims of the earthquake, liquefaction, and tsunami disaster, especially the refugees who still live in the shelter. The current situation of refugees living at the top is quite worrying. The survivors of this earthquake live in a top with $6 \times 6 \mathrm{~m}$ without a partition between the kitchen and bedrooms. It is inconceivable to meet the inner needs of a 
husband and wife who already have teenage children; of course, it is complicated to fulfill them. But they have to adapt to a new place to live, a new atmosphere and with new people.

The terms found in the communication process in the community at Taipa Beach Huntara

1. Discard

2. Ba kojo (looking for mushroom vegetables)

3. Insinuating with figurative words

\section{A solidarity that is built in the Communication Process}

Solidarity built in the communication process is when an outcast event occurs (Córdoba et al., 2021). To make a living, they scavenge for the remnants of the waste nearing its expiration date and even expired. Researchers concluded that the life process of the survivors of the Pasigala earthquake who lived in Taipa Huntara had the same background problem: they did not have legal requirements to get Huntap. However, they still hoped that the government could open their hearts to those who were victims of the Pasigala disaster.

\section{Discussion}

Taipa Beach Huntara Community Communicative Situations, Events, and Actions

In the case studied, the communicative event carried out by the Taipa Huntara community was motivated by the existence of information about discarded activities given by a child who deliberately played a bicycle in the east of the Huntara to monitor if there was any waste activity by looking at lumps of burning smoke into the air. In this study, group members who are involved in conversational situations are called informants. Recurrent events that are marked in the Taipa Huntara community communication activities are information about disposal events. This repetitive and intense event often gives rise to communicative events through discarded activities.

New terms, ideas, or ideas in the communication process of the Taipa Beach Huntara community

Disaster survivors who live in a particular social context carry out simultaneous interaction through the communication process with their environment. With the interaction process, disaster survivors have multiple dimensions of social reality that can build each other up and even tear each other down. Disaster survivors live in objective sizes and reality constructed through moments of externalization and objectification, and subjective dimensions are built through internalization. The moment of externalization, objectification, and internalization will always proceed in a dialectical manner. Magnusson (2020) prioritizes it when looking at the relationship between humans and society. Humans create a society, and likewise, community creates human beings known as externalization, objectification, and internalization. a. Events Discard externalizing moments in the communication process.

In the moment of externalization, social reality is pulled out by the individual. At this moment, social reality in the form of an adaptation process with terms, mutual agreements, values, and so on is outside of human beings. So that in the process involves self-adaptation or being adapted by these terms to the socio-cultural world. The adaptation can be through language, symbols, actions, and traditions so that the results of the agreement become shared knowledge.

b. Events Discard moments of objectivation in the communication process

In the social construction of the moment of objectification, there is a social reality that distinguishes it from other facts. This objectification occurs because of the externalization process. When in the process of externalization, all the characteristics and symbols are understood together.

c. Events Discard moments of internalization in the communication process

The new constructions built by disaster survivors at the Taipa Beach Huntara against various terms, ideas, or ideas can be categorized into four different buildings, namely:

1) Exile activity is a dirty place but is a blessing from Allah.

2) Disaster survivors view that the waste event is where they invite each other to do ba kojo activities.

3) Disaster survivors view that ba kojo is an activity to build communication and solidarity among the shelter residents.

4) Disaster survivors view that in communication activities satirizing through a song is traditional rationality. He did it because someone else did it.

\section{Research Novelist}

Researchers delivering a new term in society will occur and be conveyed well when those who get it do it intensely, and then, of course, there must be an event that mediates the repeated delivery of the term. Suppose Berger states these three things, which enable the transformation process in a society. In that case, the researcher adds that: in the method of communicating new words, ideas, ideas, or thoughts by someone in the organization, other people will accept it, other individuals and other groups. not only those who deliver. But there must be a mediating event that allows the idea to be conveyed.

The discard event is not a simple event but an event that makes it possible to convey a new value, term, idea, or idea. So the term "ba kojo" can be shown as equivalent to a term, 
idea, thought, thought or action, and cannot be conveyed if there is no intervening event.

In the communication ethnography of the people who live in the Huntara, the conception or communication system that can be raised is that communication is not just the delivery of messages so that communication occurs. Still, one communication may convey one idea, idea, or term that is new to the community. However, the delivery of ideas cannot be realized and accepted by society unless an event mediates as the medium.

\section{CONCLUSION}

The conclusions of the results of this study are as follows:

a. The ethnographic approach to communication focuses on studying the communicative behaviors of a society, which are heavily influenced by sociocultural aspects, such as the rules of interaction and culture. What is identified in this study is the presence of recurrent events or communication events that are significant and become a characteristic of communication behavior of a community group, such as the disaster survivors group in Taipa Beach Huntara in carrying out dumping activities and bakojo.

b. The terms Exile and Ba kojo in Taipa Beach disaster survivors are considered identities patterned by researchers; waste and ba kojo are created from the dialectic between individuals and society. Disposal and ba kojo are human products of disaster survivors who are socially determined in the communication process.

c. Disaster survivors initially had shared knowledge or referred to as objective reality, that waste is a trash can, dirty, dirty, and smelly, and kojo (mushroom) is a type of plant that can cause poisoning if consumed. Through the stage of objectivation, where their views of the two terms are influenced by their situation and environmental conditions, in the end, disaster survivors create a subjective reality that is different from the initial reality they previously understood.

d. Communicating is what we know communication theory is the delivery of messages or ideas or the exchange of messages to other people, that is what many people know, it turns out that communicating is not just delivering messages so that communication occurs but in communication events it can give birth to terms, ideas, or new ideas for the community, how it happened through an intense process with the district. The intensity process will occur in the presence of an event.

e. According to Berger, understanding a transformation in society requires three essential stages, namely externalization, objectivation, and internalization. However, according to the researcher, the delivery of new terms, ideas, or ideas in society cannot be created without the media intervening them, so the researcher assumes that the waste events that occurred in the Taipa Beach disaster survivors are a medium for internalizing new terms, ideas or ideas that have happened in the community-formed in their environment through communication activities in social interactions.

\section{REFERENCE}

[1] Berger, L. P., \& Luckmann, T. (1991). Tafsir Sosial atas Kenyataan. LP3ES.

[2] Córdoba, D., Peredo, A. M., \& Chaves, P. (2021). Shaping alternatives to development: Solidarity and reciprocity in the Andes during COVID-19. World Development, 139, 105323. https://doi.org/10.1016/j.worlddev.2020.105323

[3] Hymes, D. (1962). The ethnographic of speaking. University of Pennsylvania press.

[4] Hymes, D. (1972). Toward Ethnographies of Communication: The Analysis Communicative Events. In P. Giglioli (ed), Language and Social Context.

[5] Hymes, D. (1974). Fondation of sociolinguistic.An Ethnography Approach. University of Pennsylvania press.

[6] Kersten-Pejanić, R. (2019). The anti-language of feminist and queer activism. Linguistic norm-breaking and the formation of the heretical discourse in Croatia. Women's Studies International Forum, 77, 102234. https://doi.org/10.1016/j.wsif.2019.05.003

[7] Magnusson, M. S. (2020). T-patterns, external memory and masssocieties in proteins and humans: In an eye-blink the naked ape became a string-controlled citizen. Physiology \& Behavior, 227, 113146. https://doi.org/10.1016/j.physbeh.2020.113146

[8] Miles, M. B., Huberman, A. M., \& Saldana, J. (2014). Qualtative Data Analysis, Methods Source Book (3rd ed.). Sage Publications.

[9] Morris, K. A., Reese, C., Hale, R., \& Cecilia Wendler, M. (2021). Journeying through the DNP Project: A Qualitative, Descriptive Study. Journal of Professional Nursing, S8755722321001186. https://doi.org/10.1016/j.profnurs.2021.07.017

[10] Mulyana, D. (2008). Ilmu Komunikasi Suatu Pengantar. Remaja Rosdakarya.

[11] Nicodemus, B., Formentelli, M., Cagle, K. M., \& Pittman, J. (2021). Address practices of Deaf undergraduate students and faculty: A study of language, identity, and community. Journal of Pragmatics, 176, 110-123. https://doi.org/10.1016/j.pragma.2021.01.024

[12] Partelow, S. (2021). Social capital and community disaster resilience: Post-earthquake tourism recovery on Gili Trawangan, Indonesia. Sustainability Science, 16(1), 203-220. https://doi.org/10.1007/s11625-020-00854-2

[13] Penumudi, S. A., Kuppam, V. A., Kim, J. H., \& Hwang, J. (2020). The effects of target location on musculoskeletal load, task performance, and subjective discomfort during virtual reality interactions. Applied Ergonomics, 84, 103010. https://doi.org/10.1016/j.apergo.2019.103010

[14] Sybing, R. (2021). Examining dialogic opportunities in teacherstudent interaction: An ethnographic observation of the language classroom. Learning, Culture and Social Interaction, 28, 100492. https://doi.org/10.1016/j.lcsi.2021.100492

[15] van der Wilt, F., Bouwer, R., \& van der Veen, C. (2021). Dialogic classroom talk in early childhood education: The effect on language skills and social competence. Learning and Instruction, 101522. https://doi.org/10.1016/j.learninstruc.2021.101522

[16] Wekke, I. S., Sabara, Z., Samad, M. A., Yani, A., Abbas, T., \& Umam, R. (2019). EARTHQUAKE, TSUNAMI, AND SOCIETY 
International Journal of Research and Innovation in Social Science (IJRISS) |Volume V, Issue VIII, August 2021|ISSN 2454-6186

COOPERATION: EARLY FINDINGS IN PALU OF INDONESIA

POST DISASTER [Preprint]. INA-Rxiv.
https://doi.org/10.31227/osf.io/xmcyn

[17] Wong, G. K. W., \& Chan, D. L. H. (2021). Designing library- based research data management services from bottom-up. In Future Directions in Digital Information (pp. 55-68). Elsevier. https://doi.org/10.1016/B978-0-12-822144-0.00004-5 